\title{
Aptamer-targeted cell-specific RNA interference
}

\author{
Jiehua Zhou', John J Rossi ${ }^{1,2^{*}}$
}

\begin{abstract}
This potent ability of small interfering (si)RNAs to inhibit the expression of complementary RNA transcripts is being exploited as a new class of therapeutics for a variety of diseases. However, the efficient and safe delivery of siRNAs into specific cell populations is still the principal challenge in the clinical development of RNAi therapeutics. With the increasing enthusiasm for developing targeted delivery vehicles, nucleic acid-based aptamers targeting cell surface proteins are being explored as promising delivery vehicles to target a distinct disease or tissue in a cell-typespecific manner. The aptamer-based delivery of siRNAs can often enhance the therapeutic efficacy and reduce the unwanted off-target effects of siRNAs. In particular, for RNA interference-based therapeutics, aptamers represent an efficient agent for cell type-specific, systemic delivery of these oligonucleotides. In this review, we summarize recent attractive developments in creatively using cell-internalizing aptamers to deliver siRNAs to target cells. The optimization and improvement of aptamer-targeted siRNAs for clinical translation are further highlighted.
\end{abstract}

\section{Introduction}

RNA interference (RNAi) refers to the sequence-specific cleavage of messenger RNA that follows the cellular introduction of complementary, small interfering (si) RNA duplexes 21 to $25 \mathrm{nt}$ in length [1,2]. The development of siRNA-based therapeutics has progressed rapidly because of their specific and potent RNAi triggering activity $[3,4]$. Although siRNAs offer several advantages as potential new bio-drugs to treat various diseases [4-6] including cancers and HIV infection [7], the efficient delivery of siRNAs in vivo remains a crucial challenge for achieving the desired RNAi effect in clinical development $[5,8,9]$.

In particular, a targeted intracellular delivery approach for siRNAs to specific cell populations or tissues is highly desirable for the safety and efficacy of RNAibased therapeutics. Targeted delivery of therapeutics is an area of vigorous research, and numerous recent investigations have described cell type-specific siRNA delivery using different strategies. For example, siRNAs have been covalently conjugated to a targeting ligand (cholesterol [10], $\alpha$-tocopherol [11], lipophilic molecule $[12,13]$, short peptide and antibody [14,15], agonist molecule [16] and nucleic acid-based aptamer [17-20]). Alternatively, siRNAs have also been non-covalently assembled with active recognition moieties and delivery

\footnotetext{
* Correspondence: jrossi@coh.org

'Division of Molecular and Cellular Biology, Beckman Research Institute of City of Hope, City of Hope, Duarte, CA 91010, USA
}

vehicles as multifunctional targeting delivery systems, such as folate conjugated dendrimer [21], folate-conjugated phage RNAs [22-24], transferrin modified polymer/liposomes [25-28], peptide-based nanovectors [29-32], cholesterol polymers [33], antibody-mediated delivery formulations [34-48] and aptamer delivery platforms [20,49-51]. The last holds great promise for clinical translation. An ideal targeted delivery system contains two essential elements: (i) a potent therapeutic siRNA and (ii) a targeting vehicle that can selectively recognize and effectively escort cargo into a particular organ or cell. Indeed, a targeting ligand with high specificity and affinity to a cellular receptor is a major factor in establishing a targeted siRNA delivery system.

Nucleic acid-based aptamers offer some important features for targeted siRNA delivery [52-55]. Aptamers are in vitro selected nucleic acids that assume specific and stable three-dimensional shapes, thereby providing highly specific, tight binding to targeted molecules [56-58]. Given a specific molecular target, aptamers can be identified from combinatorial libraries of nucleic acids by a technique called systematic evolution of ligands by exponential enrichment (SELEX) [57]. Despite the relative youth of the aptamer field, nucleicacid aptamers have extensively blossomed in various fields ranging from diagnostics to therapeutics [59-61]. In particular, a new concept known as 'escort aptamers', a term first used by Hicke and Stephens [52] suggests a new facet of aptamer functionality: aptamers as drug-
C Biomed Central

(c) 2010 Zhou and Rossi; licensee BioMed Central Ltd. This is an Open Access article distributed under the terms of the Creative Commons Attribution License (http://creativecommons.org/licenses/by/2.0), which permits unrestricted use, distribution, and reproduction in any medium, provided the original work is properly cited. 
delivery devices. Aptamers, also described as nucleic acid versions of antibodies, possess some unique characteristics that derive from their nucleic acid composition (for example, lack of immunogenicity in vivo, relatively small physical size, straightforward chemical synthesis that makes them amenable to backbone modification, and rapid in vitro selection), making them more adaptable for specifically delivering a variety of reagents to targeted cells or tissues [59]. Moreover, precise site-specific modifications facilitate engineering of aptamers for this special purpose.

Currently, a number of aptamers targeting specific cell surface receptors have been successfully adapted for the targeted delivery of active drug substances both in vitro and in vivo, including anti-cancer drugs [53,62-72], toxins [73], enzymes [74], radionuclides [75], virus [76] and siRNAs [17-20,22,49,77] (Table 1). The cargoes are attached to the aptamers either through direct conjugation to the aptamer or through their assembly with functionalized groups appended to the aptamer and cargos. As anticipated, aptamer-mediated targeted delivery can enhance the therapeutic efficacy and reduce the toxic effects of drugs. For example, Neufeld and colleagues successfully delivered the enzyme $\alpha$-L-iduronidase to the lysosomes of cells deficient in this enzyme using aptamers targeted to the mouse transferrin receptor (TfR) [74]. For RNAi-based therapeutics, several groups have applied cell-internalizing aptamers to specifically deliver siRNAs to target cells. The most established and best characterized aptamers for siRNA delivery are the prostate-specific membrane antigen (PSMA) aptamers that bind with high affinity to PSMA [78]. Three separate groups $[18,49,77]$ have constructed distinct aptamer-siRNA conjugates for successful delivery of siRNAs into tumor cells. Functional optimization of these conjugates has been carried out [17,77] (for example, truncation or multimerization of aptamers, enhanced loading efficiency and stability of the siRNAs, and various aptamer-siRNA linkage designs and conjugation approaches), making aptamer-mediated RNAi therapeutics a promising approach for future clinical translation. There is increasing enthusiasm for generating new, more potent cell-internalizing aptamers and for developing novel and rapid selection strategies (such as cellbased SELEX [79-82] and automated SELEX workstations [83-86]) to exploit the clinical potential of aptamer-mediated delivery systems. This review focuses on recent progress in aptamer-mediated siRNA delivery for treatment of human diseases.

\section{Development of cell-internalizing aptamers}

Efficient development of new cell-type specific internalizing aptamers presents a major challenge because of the limited number of purified receptors that can be
Table 1 Cell-internalizing aptamers for targeted delivery.

\begin{tabular}{|c|c|}
\hline $\begin{array}{l}\text { Cell-internalizing } \\
\text { aptamers }\end{array}$ & Cargoes and strategy for targeted delivery \\
\hline \multirow[t]{3}{*}{$\begin{array}{l}\text { RNA aptamers against } \\
\text { PSMA }\end{array}$} & $\begin{array}{l}\text { 1) siRNA (non-covalently conjugate siRNA with } \\
\text { aptamer via a streptavidin connector [49]; } \\
\text { aptamer-siRNA chimeras }[17,18] \text { and bivalent } \\
\text { aptamer-siRNA conjugates }[77] \text { ). }\end{array}$ \\
\hline & $\begin{array}{l}\text { 2) Toxin [73] (chemically covalently conjugate } \\
\text { toxin with aptamer via SPDP reagent) }\end{array}$ \\
\hline & $\begin{array}{l}\text { 3) Nanoparticles and chemotherapeutic agents } \\
\text { [62-70] (cargoes such as dextran, docetaxel, Pt } \\
\text { (IV) and doxorubicin were encapsulated into } \\
\text { aptamer-coated nanoparticles; aptamer-Dox } \\
\text { physical conjugates via intercalation interaction) }\end{array}$ \\
\hline $\begin{array}{l}\text { RNA aptamers against } \\
\text { CD4 }\end{array}$ & $\begin{array}{l}\text { siRNA [25] (non-covalently assemble pRNA- } \\
\text { siRNA chimera with pRNA-aptamer chimera into } \\
\text { dimer or trimer) }\end{array}$ \\
\hline $\begin{array}{l}\text { RNA aptamers against } \\
\text { HIV gp120 }\end{array}$ & $\begin{array}{l}\text { siRNA [19,20] (aptamer-siRNA chimeras; non- } \\
\text { covalently conjugate siRNA with aptamer via a } \\
\text { 'sticky bridge') }\end{array}$ \\
\hline $\begin{array}{l}\text { RNA aptamers against } \\
\text { TN-C }\end{array}$ & $\begin{array}{l}\text { Radionuclide and fluorescent agents (chemically } \\
\text { covalently conjugate }{ }^{99 \mathrm{~m}} \mathrm{Tc} \text { or fluorescent } \\
\text { agents with aptamers) }\end{array}$ \\
\hline \multirow[t]{2}{*}{$\begin{array}{l}\text { DNA aptamers against } \\
\text { PTK7 }\end{array}$} & $\begin{array}{l}\text { 1) Doxorubicin [93] (chemically covalently } \\
\text { conjugate Dox with aptamer via an acid-labile } \\
\text { linkage) }\end{array}$ \\
\hline & $\begin{array}{l}\text { 2) Viral capsid [94] (chemically covalently } \\
\text { conjugate MS2 viral capsid with aptamer via an } \\
\text { oxidative coupling reaction) }\end{array}$ \\
\hline $\begin{array}{l}\text { DNA aptamers against } \\
\text { TfR }\end{array}$ & $\begin{array}{l}\text { Enzyme [74] (chemically covalently conjugate a- } \\
\text { L-iduronidase with aptamer via an oxidative } \\
\text { coupling reaction) }\end{array}$ \\
\hline $\begin{array}{l}\text { DNA aptamers against } \\
\text { NCL }\end{array}$ & $\begin{array}{l}\text { Liposomes and chemotherapeutic agents [71] } \\
\text { (cisplatin was encapsulated into liposomes that } \\
\text { was non-covalently coated with aptamers) }\end{array}$ \\
\hline $\begin{array}{l}\text { DNA aptamers against } \\
\text { MUC1 }\end{array}$ & $\begin{array}{l}\text { Photodynamic therapy agents [72] (chemically } \\
\text { covalently conjugate chlorine e6 with aptamer } \\
\text { via EDC chemistry) }\end{array}$ \\
\hline
\end{tabular}

The RNA or DNA aptamers used as delivery vehicles for various cargoes via different strategies are listed in the table.

EDC, (1-ethyl-3-[3-dimethylaminopropyl]carbodiimide hydrochloride); gp120, glycoprotein 120 (envelope protein); MUC1, mucin protein (membraneassociated glycoprotein); NCL, nucleolin (a bcl-2 mRNA binding protein); pRNA, phage RNA; PSMA, prostate-specific membrane antigen; PTK7, protein tyrosine kinase 7 (a transmembrane receptor); siRNA, small interfering RNA; SPDP, N-[O-succinimdy]-3-(2-pyridyldithio) propionate; TfR, Transferrin receptor (in mouse); $\mathrm{TN}-\mathrm{C}$, tenasin-C (a hexameric glycoprotein).

used for aptamer selection when the protein targets are insoluble or the targets are functionally part of multiprotein complexes. In these situations, traditional purified protein-based in vitro selection is not feasible. Therefore, protocols based on live cell selection present an alternative method for identifying aptamers against either cell surface or cell internal proteins. In contrast to the purified protein-based SELEX method, cell-based SELEX [79] can be performed even with unknown targets or multiprotein complexes expressed on the cell surface. Moreover, because intact living cells with many native receptor proteins are used as targets during the selection procedure, panels of new aptamers can be 
isolated from such screens [80]. Because this strategy relies essentially on the differences between the target cell population with particular features relative to the control cell population used for counterselection, (for example: defined phenotype, protein expression level, different protein conformations), multiple binding species that recognize only the target cells and not the control cells can be identified.

Despite these advantages, it should be noted that this approach does not discriminate between dead cells with reduced cell-membrane integrity and cells that are living [60]. Because dead cells can yield a sequence-independent binding of nucleic acids, cell-based SELEX can be inefficient for aptamer selection [87]. During the process of treating cells with the SELEX libraries, any damage to fragile cells might incur the risk of selection failure. Compared with the traditional SELEX methods using a single target protein [88], cell-based SELEX usually requires more selection cycles $(>20)$ and longer processing times for efficient enrichment of an aptamer population. Furthermore, increasing the number of selection cycles often favors the enrichment of nonspecific or unwanted species, which preferentially adapt to the enzymatic amplification reactions rather than to the target binding. These facts therefore demonstrate that aptamer selection involving living cells is a difficult task and is still in its infancy. Although successful in individual cases [80], further optimization of the selection schemes is required to increase the general applicability. For example, living and dead cells within a cultured cell mixture could be discriminated and separated on the basis of their different light-scattering characteristics [87].

As reported recently, several cell-internalizing aptamers against cell surface biomarkers or receptors have been successfully selected as targeting vehicles, through either traditional recombinant protein-based SELEX or cell-based SELEX strategies. To date, it has been demonstrated that RNA aptamers against PSMA [78], CD4 [89], HIV glycoprotein $120[20,90,91]$ and tenascin-C protein $(\mathrm{TN}-\mathrm{C})$ [92], and DNA aptamers against protein tyrosine kinase-7 (PTK7) [93,94], mouse Transferrin Receptor (TfR) [74], nucleolin (NCL) [71] and mucin 1 (MUC1) [72], can be used for targeted delivery purposes (Table 1). Despite these validated examples, there is still a need for additional potent cell-internalizing aptamers to expand the diversity of targeting ligands and promote their potential therapeutic applications.

\section{Aptamer-mediated cell-type specific siRNA delivery}

Cell-internalizing aptamers are well suited to cell typeor tissue-specific delivery of various cargoes because of their high affinity and specificity, and their accessibility for backbone modifications. Approaches in which aptamers and siRNAs have been linked to achieve targeted siRNA delivery and enhance RNAi potency, and to reduce unwanted side-effects have recently been described. Therefore, this section will focus on the aptamer-mediated siRNA delivery approaches. So far, only three RNA aptamers have been exploited for this purpose; however, many other aptamers such as those listed in Table 1 may also be useful for targeted siRNA delivery.

\section{Anti-PSMA RNA aptamer-mediated RNAi}

PSMA is a well-characterized transmembrane protein, which is strongly expressed in human prostate cancer and the vascular endothelium $[95,96]$. Importantly, PSMA is continually recycled from the plasma membrane and is constitutively endocytosed in PSMA-positive LNCaP cells, making it an attractive portal to deliver molecules intracellularly [66]. An anti-PSMA monoclonal antibody was demonstrated to promote the internalization rate. Using a purified fusion target protein containing a modified extracellular form of PSMA, Lupold et al. previously selected from an RNA library two 2'-fluoro (2'-F)-modified RNase-resistant RNA aptamers (A-9 and A-10) with low nanomolar affinity binding constants [78]. They also quantified the affinity of each aptamer for PSMA by measuring the inhibition of $\mathrm{N}$-acetylated $\alpha$-linked acidic dipeptidase (NAALADase) activity. Aptamer A-9 inhibited PSMA noncompetitively with an average $K_{i}$ of $2.1 \mathrm{nM}$, whereas aptamer A-10 inhibited competitively with an average $K_{i}$ of $11.9 \mathrm{nM}$. Because these anti-PSMA aptamers can be internalized, they have recently been engineered for cell-type specific delivery of various cargoes $[53,54,61]$, such as chemotherapeutic agents, drug-encapsulated nanoparticles, toxins, enzymes and siRNAs.

Three independent groups have successfully employed the anti-PSMA RNA aptamers to specifically deliver siRNAs to target cells (Figure 1). In a proof of concept study [49], Chu et al. recently reported successful noncovalent conjugation of biotinylated anti-PSMA aptamer (A-9) with biotinylated 27-mer lamin A/C or GAPDH siRNAs via a modular streptavidin connector (Figure 1a). To enhance siRNA release in the cytoplasm, a reducible disulfide linker was designed between the sense strand of siRNA and the biotin group. By using such a streptavidin connector, two aptamers and two siRNAs were elegantly assembled into a multivalent construct, displaying effective PSMA receptor-mediated internalization of aptamer-siRNAs and specific silencing of the targeted transcripts in tumor cells.

A somewhat different approach was developed by Giangrande and colleagues [18], in which a 2'-F-modified anti-PSMA aptamer (A-10) was covalently appended to the sense strand of a 21-mer siRNA 


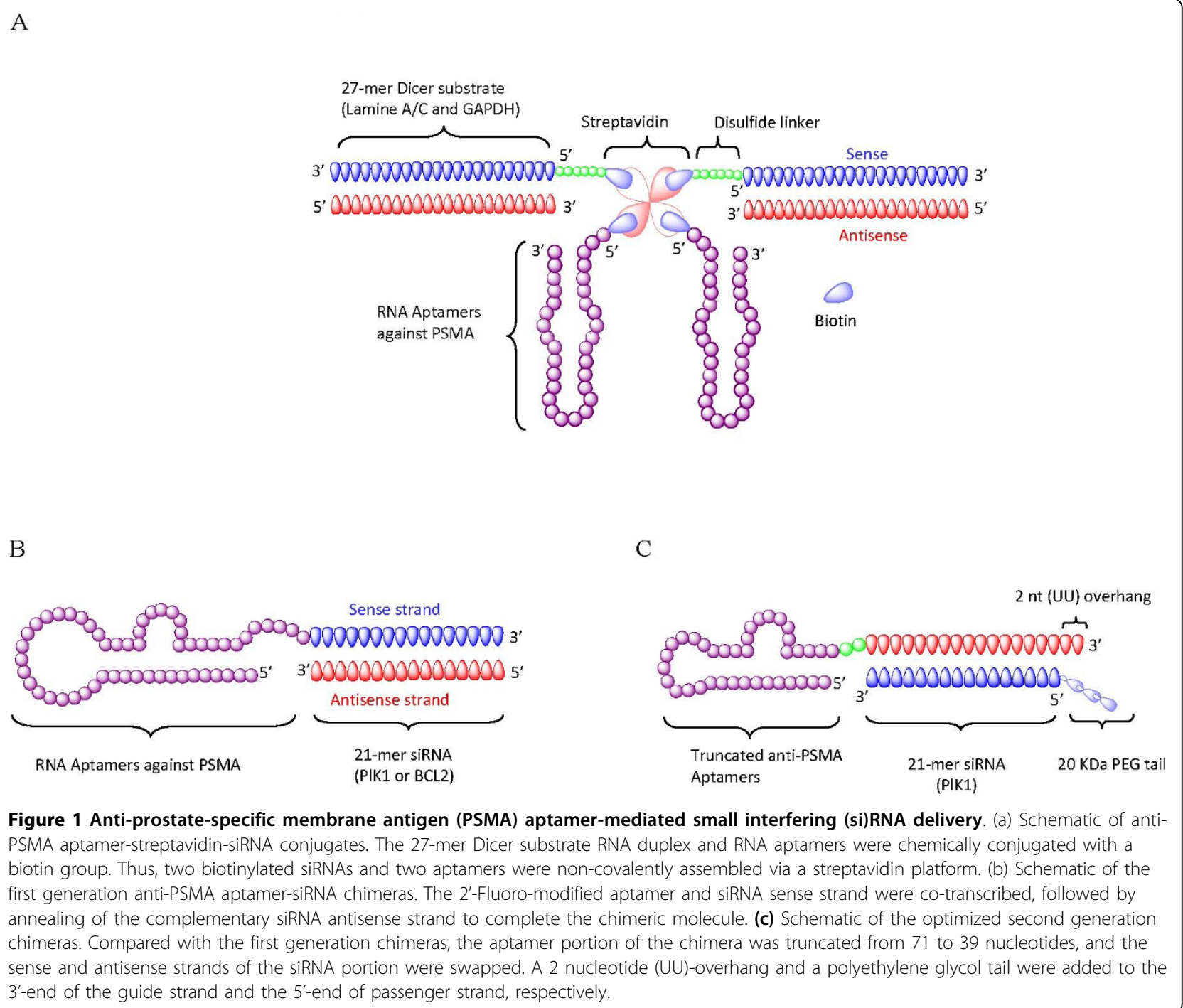

portion, which in turn was hybridized to the 21-mer antisense strand (Figure 1b). The resulting aptamersiRNA chimeric RNA was shown to be selectively internalized into cells expressing PSMA, and to effectively knock down expression of the targeted the tumor survival genes (PLK1 and BCL2) both in cell culture and in vivo after intratumoral delivery. Because this delivery system consists only of RNA components, it offers several potential advantages as a therapeutic agent, including lack of immunogenicity, the possibility for chemical synthesis, and stabilizing modifications for in vivo application.

Although aptamer-siRNA chimeras can be directly administered to localized targets (for example, intratumoral delivery), systemic administration will be required for many diseases. In general, greater therapeutic doses are required for systemic administration, leading to higher costs and side effects. Most recently, Giangrande and colleagues addressed this issue by optimizing their previous PSMA-siRNA chimeric design to achieve enhanced inhibition of prostate cancer xenograft growth via systemic administration (Figure 1c) [17]. First, the aptamer portion of the PSMA A10-Plk1 chimera was truncated from 71 to 39 nucleotides, while still maintaining high binding affinity. Most importantly, the truncated version (containing the aptamer and sense strand of the siRNA) comprising a total of 64 nucleotides makes this amenable to chemical synthesis. Second, the silencing potency was enhanced through structural modifications of the siRNA portion, enabling more efficient incorporation of the siRNA by the cellular RNAi machinery. The group then added a 2-nucleotide (UU) overhang at the 3 ' end of the siRNA duplex, but also swapped the positions of the passenger and guide strands of the siRNA. These modifications favor Dicer recognition and loading of the guide strand (containing 
the two base 3' overhang) into an RNA-induced silencing complex (RISC), hence increasing the silencing activity and specificity. By appending a polyethylene glycol moiety with molecular weight $20 \mathrm{kDa}$ onto the siRNA passenger, the circulating half-life of the chimeric molecule was substantially increased and the bioavailability was markedly improved, leading to prolonged silencing in vivo. As a result of these efforts, the optimized second-generation aptamer-siRNA chimeras (Figure 1c) resulted in pronounced regression of PSMAexpressing tumors after systemic administration in athymic mice. Additionally, the therapeutic dose of the new chimera was dramatically reduced from $1 \mathrm{nmol}$ on each of 10 successive days $(10 \times 1 \mathrm{nmol})$ to $0.25 \mathrm{nmol}$ in every other day for a total of 10 days $(5 \times 0.25 \mathrm{nmol})$, minimizing both the cost of treatment and the risk of harmful side effects.

Other efforts to further refine aptamer-mediated siRNA delivery and targeting efficiency are being attempted through multimerization of the aptamer portion. Previous studies with aptamers have revealed that multivalent versions of aptamers can increase the potency and antitumor response, and promote receptor activation [97-100]. The multivalent aptamer-siRNA construct has also been recently exploited for facilitating receptor internalization, further improving the therapeutic potential. Wullner et al. generated two different bivalent anti-PSMA aptamer-siRNA chimeras in which the siRNAs targeted eukaryotic elongation factor 2 [77]. Their modifications included using the siRNA itself as a linker to join the two aptamers or appending the siRNAs onto the 3' ends of each aptamer. Compared with the monovalent aptamer-siRNA chimeras (55\% target knockdown), these bivalent aptamer-siRNA constructs resulted in an almost complete loss of PSMA-positive cell viability, suggesting that bivalent aptamers definitely promote internalization of chimeras. These efforts have encouraged new thinking in the design of multiple aptamer-siRNA conjugates.

\section{Anti-CD4 RNA aptamer-mediated RNAi}

The CD4 receptor, a glycoprotein expressed on the surface of certain subsets of T lymphocytes [101-103], is a primary receptor used by HIV-1 to gain entry into host $\mathrm{T}$ cells. It was previously reported that overexpressed CD4 protein in T helper cells can be endocytosed [104]. Aptamers targeting CD4 were produced by immobilizing soluble, recombinant CD4 antigen onto Sepharose beads, allowing elution of unbound oligonucleotides and retention of bound species, which were further amplified for the next selection rounds [89]. Using this approach, 2'-F-modified RNA aptamers with high CD4 affinity were identified. The ability of CD4 aptamers to block functional $\mathrm{T}$ cell responses was tested using an allogeneic mixed lymphocyte reaction (MLR), a complex in vitro assay of $\mathrm{T}$-cell recognition and responsiveness, in which the comparative standard is the W3/25 CD4 monoclonal antibody, which binds to the same site as the tested aptamer clones. Thus, the ability to block MLR correlates with CD4 binding activity. These aptamers showed inhibitory effects in a CD4-specific manner. This CD4-specific aptamer has been assembled into a multifunctional nano-device for targeted delivery of siRNAs in a T-cell line engineered to overexpress CD4 $[22,50]$.

Recently, anti-CD4 RNA aptamers have been exploited for targeted delivery of siRNAs [22,105]. The self-assembling bacteriophage phi29 RNA (pRNA) was joined with the anti-CD4 aptamer and allowed to form a nano-complex with a pRNA-siRNA chimera. It was previously demonstrated that pRNAs can be accurately assembled through interlocking right- and left-hand loops into various oligomers (dimer, trimer, hexamer) ranging in size from nanometers to micrometers [51,106]. The pRNA itself can be fused with various agents (folate, aptamer, siRNA, dye, antitumor drugs), while still allowing oligomerization of the pRNAs [107]. For example, as shown in Figure 2, two pRNA molecules were respectively fused with siRNAs (against survivin, green fluorescent protein (GFP), Bcl2 antagonist of cell death (BAD) or luciferase) and the anti-CD4 aptamer. Through the interaction of right and left interlocking loops, the two chimeric pRNAs could be precisely dimerized into a stable nanovector of approximately $25 \mathrm{~nm}$ in diameter. The nano-scale RNA dimer was also shown to be effectively internalized into a CD4-overexpressing $\mathrm{T}$ cell line, and the siRNAs consequently knocked down the expression levels of the targeted surviving or enhanced GFP mRNAs. The direct correlation between CD4 expression level and the internalization/silencing activity of the siRNAs also provided proof of anti-CD4 aptamer-mediated cell-specific siRNA delivery. Similarly, a trimeric conjugate was engineered in the same way. Three chimeric pRNA building blocks (one fused with the CD4 aptamer, another with an siRNA and a third with a fluorescent molecule) were assembled into a multifunctional nanodevice, which elicited siRNA-mediated target knockdown and also provided molecular imaging via the fluorescent dye. This self-assembling nano device may improve the in vivo kinetics and enhance the therapeutic efficacies of the delivered siRNAs.

\section{Anti-gp120 RNA aptamer-mediated RNAi}

The HIV-1-encoded gp120 protein, a glycoprotein envelope on the surface of HIV-1, plays an important role in viral entry into CD4 cells $[101,103]$. The interaction of gp120 and CD4 triggers HIV-1 entry and initiates cell fusion [108-111]. Recently, a chimeric Fab gp120 antibody fragment-protamine fusion was demonstrated to facilitate receptor-specific siRNA uptake into 


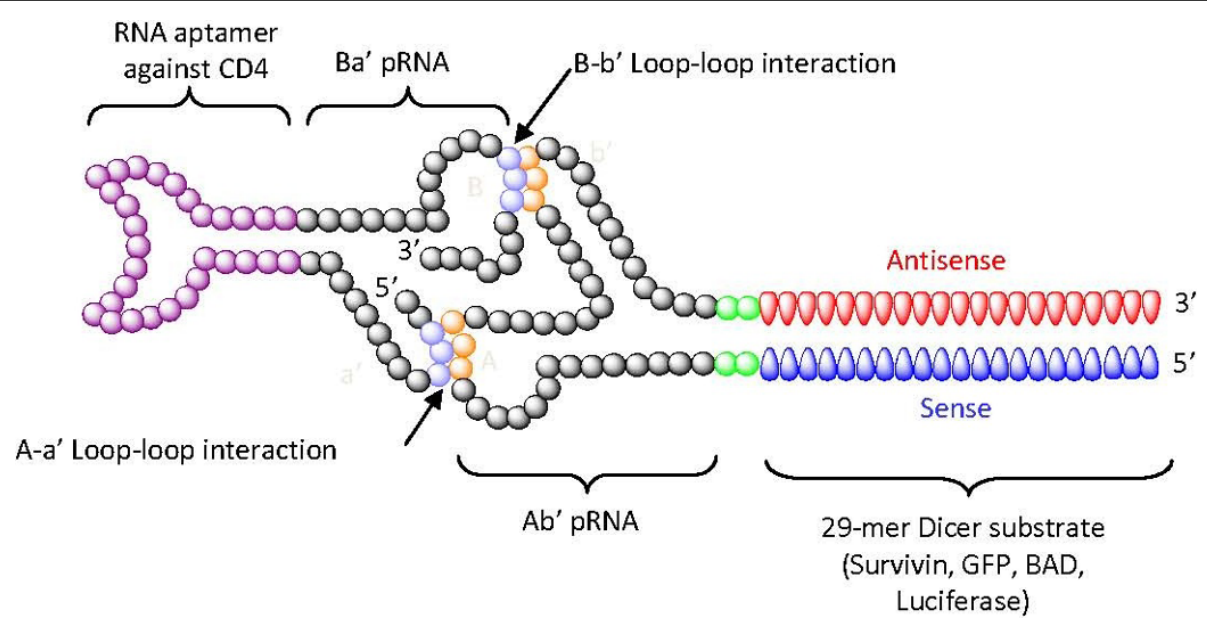

Figure 2 Anti-CD4 aptamer mediated small interfering (si)RNA delivery. Schematic of a dimer of the chimeric phage (p)RNA-CD4 aptamer and chimeric pRNA-siRNA. The anti-CD4 aptamer or siRNAs were non-covalently joined via phi29 RNAs containing complementary loop domains. Through interactions of the interlocking left and right loops, chimeric phi29 RNAs could be fabricated into the dimers shown as an example.

cells expressing the HIV-1 gp120 envelope protein, suggesting this protein as a new molecular target for receptor-mediated siRNA delivery [40]. Several 2'-F modified anti-HIV gp120 RNA aptamers have been isolated with the use of a BIAcore biosensor system (Stevenage, United Kingdom) $[90,91,112,113]$ or conventional nitrocellulose filter binding of aptamers to recombinant proteins [20]. The selected aptamers can specifically bind to and be rapidly internalized into cells expressing the HIV-1 envelope protein. In addition, the aptamers alone can neutralize HIV-1 infectivity.

Recently, we used gp120 aptamer-siRNA chimeras for cell type-specific delivery of siRNAs in cultured cells and in a HIV-1 infected Rag-Hu mouse model. The gp120 aptamer (Figure 3a), was covalently linked to siRNAs that target the HIV-1 tat/rev common exon [19]. Because both the aptamer and the siRNA can inhibit HIV-1 replication by respectively blocking the gp120CD4 receptor interaction and silencing HIV-1 tat/rev expression, this novel anti-gp120 aptamer-siRNA chimera possesses a dual inhibitory function. Treatment of HIV-1-infected cells with these chimeras resulted in the selective gp120-mediated internalization of the aptamersiRNA by endocytosis and the specific silencing of the targeted mRNA transcript. Interestingly, a small change in the length of the siRNA portion of the chimera from $21 \mathrm{bp}$ to $27 \mathrm{bp}$ resulted in enhanced silencing potency. This was the result of Dicer processing of the 27-mer from the aptamer and perhaps a more efficient handoff of the processed siRNA to RISC. These results demonstrated that HIV-1 gp120 expressed on the surface of HIV-1-infected cells represents a unique target for aptamer-mediated siRNA delivery.
In a study by Zhou et al. [20], a 'sticky bridge' strategy was developed to non-covalently conjugate the aptamer with various siRNAs (Figure $3 \mathrm{~b}$ ). In this design format, one pair of complementary GC-rich sticky bridge sequences was chemically attached to the 3 ' end of the aptamer. The complement to this sequence was attached to one of the two siRNA, strands and the aptamer and siRNA were joined by Watson-Crick base pairing. A flexible three-carbon atom hinge (C3) was added as a spacer between the adhesive (sticky) sequence and the aptamer to allow spatial and structural flexibility. Importantly, this sticky bridge-based strategy can be used to facilitate the effective interchange of different siRNAs with a single aptamer, which is required to avert viral resistance to the siRNA component. We combined three different siRNAs with the gp120 aptamer: one against the HIV-1 tat/rev gene, and two siRNAs targeting the HIV host dependency factors CD4 and transportin 3, respectively. The specific binding and internalization of the aptamer-siRNA conjugates into gp120-expressing cells was demonstrated by confocal microscopy, and the aptamer-'sticky bridge'-siRNA combinations downregulated targeted gene expression and suppressed HIV replication in cell culture. Additionally, the aptamersiRNA combinations also served as dual-function inhibitors, providing additive efficacy. These results demonstrated the potential use of aptamer-siRNA conjugates as a systemic, cell type-specific, siRNA cocktail delivery system for anti-HIV-1 therapy.

Most recently, we tested the anti-HIV efficacy of these aptamer-siRNA dual inhibitors in a humanized mouse model (P. Neff et al., manuscript submitted to Science Translational Medicine). In this model system, the 
A

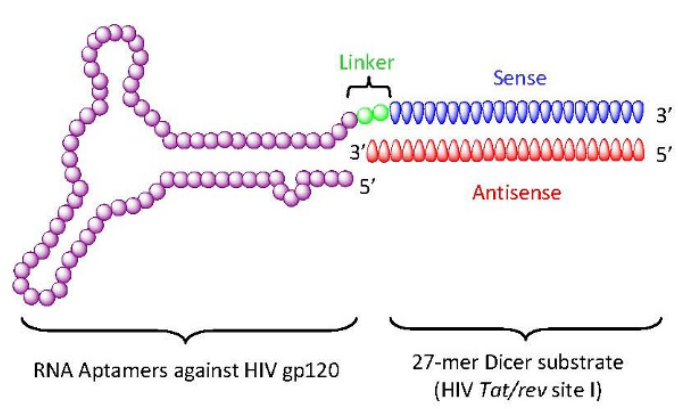

B

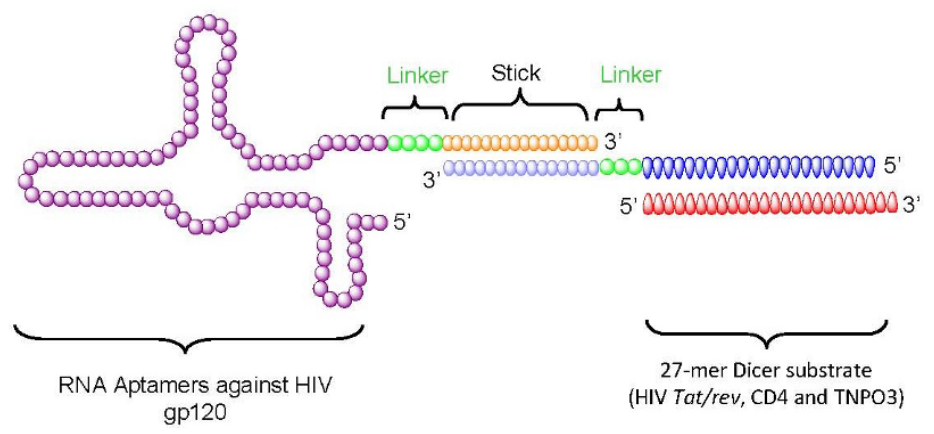

Figure 3 Anti-HIV-1 gp120 aptamer-mediated small interfering (si)RNA delivery. (a) Schematic of the anti-HIV-1 gp120 aptamer-siRNA chimeras. The anti-gp120 aptamer binds to gp120 and the 27-mer Dicer substrate RNA duplex targets a common exon of the HIV-1 tat/rev transcript. Dicer processing results in 21-mer siRNAs that are incorporated into an RNA-induced silencing complex (RISC). (b) Schematic of the anti-HIV gp120 aptamer-'sticky bridge'-siRNA conjugates. Either the antisense or the sense strand of the 27-mer Dicer substrate RNA duplex and the aptamer were attached with to complementary 'sticky' sequences. After a simple annealing, they form stable base pairs.

humanized Rag2 $2^{-/-} \gamma \mathrm{c}^{-/-}$mice (RAG-hu) were treated with human CD34 hematopoietic progenitor cells, which engraft and differentiate in a variety of human hematopoietic lineages. The mature $\mathrm{T}$ cells and monocytes were infected with the HIV-1 NL4.3 virus. After 3 weeks of viral replication, the animals were injected intravenously once weekly with the aptamer-siRNA conjugates. We observed a dramatic decrease in viral load in all the treated animals, in most cases to undetectable levels within a week after the intravenous administration of the chimera. The suppression of viral load averaged three logs of reduction relative to controls, and persisted throughout and beyond the treatment period in several of the animals. Most importantly, the aptamer-siRNA treatment completely prevented T-cell depletion mediated by viral infection. Therefore, the capacity to achieve marked viral suppression in vivo together with restoration of CD4 $\mathrm{T}$ cell levels using aptamer-siRNA constructs should pave the way for implementing novel therapeutic strategies for treating HIV disease. In particular, these dual-action constructs will be useful for treatment of patients who do not respond to highly active anti-retroviral therapy, the standard multi-drug treatment that has proved so effective in battling AIDS.

\section{Conclusions and perspectives}

Since the first description of RNA interference triggered by double-stranded RNA in 1998, RNAi has rapidly become one of the methods of choice for gene function studies and is also extensively being exploited for therapeutic applications. The successful use of siRNAs for therapeutic purposes requires safe and efficient intracellular delivery to specific cells and tissues. Nucleic acidbased aptamers have many favorable characteristics, including high binding sensitivity and specificity, small size and ease of in vitro selection, making them very attractive for a variety of uses in molecular targeting. In this regard, nucleic acid aptamers targeting cell surface proteins are emerging as a promising class of delivery vehicles to target a particular cell population or tissue, thus providing enhanced therapeutic potency and reduced cellular toxicity.

To date, significant advances have been made to develop cell-internalizing aptamers as a vehicle to deliver siRNAs to diseased cells/tissues in a cell type-specific manner. Several examples discussed in this review (for example, covalent aptamer-siRNA chimeras, noncovalent aptamer-connector-siRNA conjugates and aptamer-functionalized nanovectors loaded with siRNAs), provide complementary approaches for combining the power of RNAi with aptamer technology, providing a versatile technology platform for the treatment of various diseases.

Despite substantial progress in aptamer-mediated siRNA delivery, two major efforts are still required for clinical translation: (i) the development of more efficient selection methods to generate new cell-internalizing aptamers with high affinity and (ii) the development of easier conjugation strategies for siRNA joining to aptamers.

\section{Acknowledgements}

This work was supported by grants from the National Institutes of Health Al29329, Al42552 and HL07470 awarded to JJR.

\section{Author details}

${ }^{1}$ Division of Molecular and Cellular Biology, Beckman Research Institute of City of Hope, City of Hope, Duarte, CA 91010, USA. ${ }^{2}$ Irell and Manella Graduate School of Biological Sciences, Beckman Research Institute of City of Hope, City of Hope, Duarte, CA 91010, USA. 


\section{Authors' contributions}

JZ drafted the manuscript. JR revised it and gave final approval of the version to be published. All authors read and approved the final manuscript.

\section{Competing interests}

The authors declare that they have no competing interests.

Received: 2 December 2009

Accepted: 1 February 2010 Published: 1 February 2010

\section{References}

1. Fire A, Xu S, Montgomery MK, Kostas SA, Driver SE, Mello CC: Potent and specific genetic interference by double-stranded RNA in Caenorhabditis elegans. Nature 1998, 391:806-811.

2. Zamore PD, Tuschl T, Sharp PA, Bartel DP: RNAi: double-stranded RNA directs the ATP-dependent cleavage of mRNA at 21 to 23 nucleotide intervals. Cell 2000, 101:25-33.

3. de Fougerolles A, Vornlocher HP, Maraganore J, Lieberman J: Interfering with disease: a progress report on siRNA-based therapeutics. Nat Rev Drug Discov 2007, 6:443-453.

4. Kim DH, Rossi JJ: Strategies for silencing human disease using RNA interference. Nat Rev Genet 2007, 8:173-184.

5. Castanotto D, Rossi Jj: The promises and pitfalls of RNA-interferencebased therapeutics. Nature 2009, 457:426-433.

6. Song E, Lee SK, Wang J, Ince N, Ouyang N, Min J, Chen J, Shankar P, Lieberman J: RNA interference targeting Fas protects mice from fulminant hepatitis. Nat Med 2003, 9:347-351.

7. Scherer L, Rossi JJ, Weinberg MS: Progress and prospects: RNA-based therapies for treatment of HIV infection. Gene Ther 2007, 14:1057-1064.

8. De Paula D, Bentley MV, Mahato RI: Hydrophobization and bioconjugation for enhanced siRNA delivery and targeting. Rna 2007, 13:431-456.

9. Whitehead KA, Langer R, Anderson DG: Knocking down barriers: advances in siRNA delivery. Nat Rev Drug Discov 2009, 8:129-138.

10. Soutschek J, Akinc A, Bramlage B, Charisse K, Constien R, Donoghue M, Elbashir S, Geick A, Hadwiger P, Harborth J, John M, Kesavan V, Lavine G, Pandey RK, Racie T, Rajeev KG, Röhl I, Toudjarska I, Wang G, Wuschko S, Bumcrot D, Koteliansky V, Limmer S, Manoharan M, Vornlocher HP: Therapeutic silencing of an endogenous gene by systemic administration of modified siRNAs. Nature 2004, 432:173-178.

11. Nishina K, Unno T, Uno Y, Kubodera T, Kanouchi T, Mizusawa H, Yokota T: Efficient in vivo delivery of siRNA to the liver by conjugation of alphatocopherol. Mol Ther 2008, 16:734-740.

12. Wolfrum C, Shi S, Jayaprakash KN, Jayaraman M, Wang G, Pandey RK, Rajeev KG, Nakayama T, Charrise K, Ndungo EM, Zimmermann T, Koteliansky V, Manoharan M, Stoffel M: Mechanisms and optimization of in vivo delivery of lipophilic siRNAs. Nat Biotechnol 2007, 25:1149-1157.

13. Lorenz C, Hadwiger P, John M, Vornlocher HP, Unverzagt C: Steroid and lipid conjugates of siRNAs to enhance cellular uptake and gene silencing in liver cells. Bioorg Med Chem Lett 2004, 14:4975-4977.

14. Muratovska A, Eccles MR: Conjugate for efficient delivery of short interfering RNA (siRNA) into mammalian cells. FEBS Lett 2004, 558:63-68.

15. Chiu YL, Ali A, Chu CY, Cao H, Rana TM: Visualizing a correlation between siRNA localization, cellular uptake, and RNAi in living cells. Chem Biol 2004, 11:1165-1175.

16. Kortylewski M, Swiderski P. Herrmann A, Wang L, Kowolik C, Kujawski M, Lee H, Scuto A, Liu Y, Yang C, Deng J, Soifer HS, Raubitschek A, Forman S, Rossi JJ, Pardoll DM, Jove R, Yu H: In vivo delivery of siRNA to immune cells by conjugation to a TLR9 agonist enhances antitumor immune responses. Nat Biotechnol 2009, 27:925-932.

17. Dassie JP, Liu XY, Thomas GS, Whitaker RM, Thiel KW, Stockdale KR, Meyerholz DK, McCaffrey AP, McNamara JO, Giangrande PH: Systemic administration of optimized aptamer-siRNA chimeras promotes regression of PSMA-expressing tumors. Nat Biotechnol 2009, 27:839-849.

18. McNamara JO, Andrechek ER, Wang Y, Viles KD, Rempel RE, Gilboa E, Sullenger BA, Giangrande PH: Cell type-specific delivery of siRNAs with aptamer-siRNA chimeras. Nat Biotechnol 2006, 24:1005-1015.

19. Zhou J, Li H, Li S, Zaia J, Rossi JJ: Novel dual inhibitory function aptamersiRNA delivery system for HIV-1 therapy. Mol Ther 2008, 16:1481-1489.

20. Zhou J, Swiderski P, Li H, Zhang J, Neff CP, Akkina R, Rossi JJ: Selection, characterization and application of new RNA HIV gp 120 aptamers for facile delivery of Dicer substrate siRNAs into HIV infected cells. Nucleic Acids Res 2009, 37:3094-109.

21. Kim SH, Mok H, Jeong JH, Kim SW, Park TG: Comparative evaluation of target-specific GFP gene silencing efficiencies for antisense ODN, synthetic siRNA, and siRNA plasmid complexed with PEI-PEG-FOL conjugate. Bioconjug Chem 2006, 17:241-244.

22. Guo S, Tschammer N, Mohammed S, Guo P: Specific delivery of therapeutic RNAs to cancer cells via the dimerization mechanism of phi29 motor pRNA. Hum Gene Ther 2005, 16:1097-1109.

23. Li L, Liu J, Diao Z, Shu D, Guo P, Shen G: Evaluation of specific delivery of chimeric phi29 pRNA/siRNA nanoparticles to multiple tumor cells. Mol Biosyst 2009, 5:1361-1368.

24. Zhang HM, Su Y, Guo S, Yuan J, Lim T, Liu J, Guo P, Yang D: Targeted delivery of anti-coxsackievirus siRNAs using ligand-conjugated packaging RNAs. Antiviral Res 2009, 83:307-316.

25. Hu-Lieskovan S, Heidel JD, Bartlett DW, Davis ME, Triche TJ: Sequencespecific knockdown of EWS-FLI1 by targeted, nonviral delivery of small interfering RNA inhibits tumor growth in a murine model of metastatic Ewing's sarcoma. Cancer Res 2005, 65:8984-8992.

26. Bellocq NC, Pun SH, Jensen GS, Davis ME: Transferrin-containing, cyclodextrin polymer-based particles for tumor-targeted gene delivery. Bioconjug Chem 2003, 14:1122-1132.

27. Heidel JD, Yu Z, Liu JY, Rele SM, Liang Y, Zeidan RK, Kornbrust DJ, Davis ME: Administration in non-human primates of escalating intravenous doses of targeted nanoparticles containing ribonucleotide reductase subunit M2 siRNA. Proc Natl Acad Sci USA 2007, 104:5715-5721.

28. Pal A, Ahmad A, Khan S, Sakabe I, Zhang C, Kasid UN, Ahmad I: Systemic delivery of RafsiRNA using cationic cardiolipin liposomes silences Raf-1 expression and inhibits tumor growth in xenograft model of human prostate cancer. Int J Oncol 2005, 26:1087-1091.

29. Schiffelers RM, Ansari A, Xu J, Zhou Q, Tang Q, Storm G, Molema G, Lu PY, Scaria PV, Woodle MC: Cancer siRNA therapy by tumor selective delivery with ligand-targeted sterically stabilized nanoparticle. Nucleic Acids Res 2004, 32:e149.

30. Kang H, DeLong R, Fisher MH, Juliano RL: Tat-conjugated PAMAM dendrimers as delivery agents for antisense and siRNA oligonucleotides. Pharm Res 2005, 22:2099-2106.

31. Howard KA, Rahbek UL, Liu X, Damgaard CK, Glud SZ, Andersen MO, Hovgaard MB, Schmitz A, Nyengaard JR, Besenbacher F, Kjems J: RNA interference in vitro and in vivo using a novel chitosan/siRNA nanoparticle system. Mol Ther 2006, 14:476-484

32. Urban-Klein B, Werth $\mathrm{S}$, Abuharbeid $\mathrm{S}$, Czubayko F, Aigner A: RNAimediated gene-targeting through systemic application of polyethylenimine (PEI)-complexed siRNA in vivo. Gene Ther 2005, 12:461-466.

33. Kim WJ, Christensen LV, Jo S, Yockman JW, Jeong JH, Kim YH, Kim SW: Cholesteryl oligoarginine delivering vascular endothelial growth factor siRNA effectively inhibits tumor growth in colon adenocarcinoma. Mol Ther 2006, 14:343-350.

34. Patri AK, Myc A, Beals J, Thomas TP, Bander NH, Baker JR Jr: Synthesis and in vitro testing of $J 591$ antibody-dendrimer conjugates for targeted prostate cancer therapy. Bioconjug Chem 2004, 15:1174-1181.

35. Kostiainen MA, Szilvay GR, Lehtinen J, Smith DK, Linder MB, Urtti A, Ikkala O: Precisely defined protein-polymer conjugates: construction of synthetic DNA binding domains on proteins by using multivalent dendrons. ACS Nano 2007, 1:103-113.

36. Pun SH, Davis ME: Development of a nonviral gene delivery vehicle for systemic application. Bioconjug Chem 2002, 13:630-639.

37. Morrissey DV, Lockridge JA, Shaw L, Blanchard K, Jensen K, Breen W, Hartsough K, Machemer L, Radka S, Jadhav V, Vaish N, Zinnen S, Vargeese C, Bowman K, Shaffer CS, Jeffs LB, Judge A, MacLachlan I, Polisky B: Potent and persistent in vivo anti-HBV activity of chemically modified siRNAs. Nat Biotechnol 2005, 23:1002-1007.

38. Zimmermann TS, Lee AC, Akinc A, Bramlage B, Bumcrot D, Fedoruk MN, Harborth J, Heyes JA, Jeffs LB, John M, Judge AD, Lam K, McClintock K, Nechev LV, Palmer LR, Racie T, Röhl I, Seiffert S, Shanmugam S, Sood V, Soutschek J, Toudjarska I, Wheat AJ, Yaworski E, Zedalis W, Koteliansky V, Manoharan M, Vornlocher HP, MacLachlan I: RNAi-mediated gene silencing in non-human primates. Nature 2006, 441:111-114. 
39. Palliser D, Chowdhury D, Wang QY, Lee SJ, Bronson RT, Knipe DM, Lieberman J: An siRNA-based microbicide protects mice from lethal herpes simplex virus 2 infection. Nature 2006, 439:89-94.

40. Song E, Zhu P, Lee SK, Chowdhury D, Kussman S, Dykxhoorn DM, Feng $Y$, Palliser D, Weiner DB, Shankar P, Marasco WA, Lieberman J: Antibody mediated in vivo delivery of small interfering RNAs via cell-surface receptors. Nat Biotechnol 2005, 23:709-717.

41. Sorensen DR, Leirdal M, Sioud M: Gene silencing by systemic delivery of synthetic siRNAs in adult mice. J Mol Biol 2003, 327:761-766.

42. Zhang $Y$, Cristofaro $P$, Silbermann $R$, Pusch $O$, Boden D, Konkin $T$, Hovanesian V, Monfils PR, Resnick M, Moss SF, Ramratnam B: Engineering mucosal RNA interference in vivo. Mol Ther 2006, 14:336-342.

43. Ge Q, Filip L, Bai A, Nguyen T, Eisen HN, Chen J: Inhibition of influenza virus production in virus-infected mice by RNA interference. Proc Natl Acad Sci USA 2004, 101:8676-8681.

44. Takei Y, Kadomatsu K, Yuzawa Y, Matsuo S, Muramatsu T: A small interfering RNA targeting vascular endothelial growth factor as cancer therapeutics. Cancer Res 2004, 64:3365-3370.

45. Peer D, Park EJ, Morishita Y, Carman CV, Shimaoka M: Systemic leukocytedirected siRNA delivery revealing cyclin D1 as an anti-inflammatory target. Science 2008, 319:627-630.

46. Peer D, Zhu P, Carman CV, Lieberman J, Shimaoka M: Selective gene silencing in activated leukocytes by targeting siRNAs to the integrin lymphocyte function-associated antigen-1. Proc Natl Acad Sci USA 2007, 104:4095-4100.

47. Kumar P, Wu H, McBride JL, Jung KE, Kim MH, Davidson BL, Lee SK, Shankar $P$, Manjunath N: Transvascular delivery of small interfering RNA to the central nervous system. Nature 2007, 448:39-43.

48. Kumar P, Ban HS, Kim SS, Wu H, Pearson T, Greiner DL, Laouar A, Yao J, Haridas V, Habiro K, Yang YG, Jeong JH, Lee KY, Kim YH, Kim SW, Peipp M Fey GH, Manjunath N, Shultz LD, Lee SK, Shankar P: T cell-specific siRNA delivery suppresses HIV-1 infection in humanized mice. Cell 2008, 134:577-586

49. Chu TC, Twu KY, Ellington AD, Levy M: Aptamer mediated siRNA delivery. Nucleic Acids Res 2006, 34:e73.

50. Khaled A, Guo S, Li F, Guo P: Controllable self-assembly of nanoparticles for specific delivery of multiple therapeutic molecules to cancer cells using RNA nanotechnology. Nano Lett 2005, 5:1797-1808.

51. Guo P, Zhang C, Chen C, Garver K, Trottier M: Inter-RNA interaction of phage phi29 pRNA to form a hexameric complex for viral DNA transportation. Mol Cell 1998, 2:149-155.

52. Hicke BJ, Stephens AW: Escort aptamers: a delivery service for diagnosis and therapy. J Clin Invest 2000, 106:923-928.

53. Levy-Nissenbaum E, Radovic-Moreno AF, Wang AZ, Langer R, Farokhzad OC: Nanotechnology and aptamers: applications in drug delivery. Trends Biotechnol 2008, 26:442-449.

54. Yan AC, Levy M: Aptamers and aptamer targeted delivery. RNA Biol 2009, 6:316-320.

55. Cerchia L, Giangrande PH, McNamara JO, de Franciscis V: Cell-specific aptamers for targeted therapies. Methods Mol Biol 2009, 535:59-78.

56. Robertson DL, Joyce GF: Selection in vitro of an RNA enzyme that specifically cleaves single-stranded DNA. Nature 1990, 344:467-468.

57. Tuerk C, Gold L: Systematic evolution of ligands by exponential enrichment: RNA ligands to bacteriophage T4 DNA polymerase. Science 1990, 249:505-510

58. Ellington AD, Szostak JW: In vitro selection of RNA molecules that bind specific ligands. Nature 1990, 346:818-822.

59. Famulok M, Hartig JS, Mayer G: Functional aptamers and aptazymes in biotechnology, diagnostics, and therapy. Chem Rev 2007, 107:3715-3743.

60. Mayer G: The chemical biology of aptamers. Angew Chem Int Ed Engl 2009, 48:2672-2689.

61. Thiel KW, Giangrande PH: Therapeutic applications of DNA and RNA aptamers. Oligonucleotides 2009, 19:209-222.

62. Bagalkot V, Farokhzad OC, Langer R, Jon S: An aptamer-doxorubicin physical conjugate as a novel targeted drug-delivery platform. Angew Chem Int Ed Engl 2006, 45:8149-8152.

63. Cheng J, Teply BA, Sherifi I, Sung J, Luther G, Gu FX, Levy-Nissenbaum E, Radovic-Moreno AF, Langer R, Farokhzad OC: Formulation of functionalized PLGA-PEG nanoparticles for in vivo targeted drug delivery. Biomaterials 2007, 28:869-876.
64. Dhar S, Gu FX, Langer R, Farokhzad OC, Lippard SJ: Targeted delivery of cisplatin to prostate cancer cells by aptamer functionalized Pt(IV) prodrug-PLGA-PEG nanoparticles. Proc Natl Acad Sci USA 2008, 105:17356-17361.

65. Farokhzad OC, Cheng J, Teply BA, Sherifi I, Jon S, Kantoff PW, Richie JP, Langer R: Targeted nanoparticle-aptamer bioconjugates for cancer chemotherapy in vivo. Proc Natl Acad Sci USA 2006, 103:6315-6320.

66. Farokhzad OC, Jon S, Khademhosseini A, Tran TN, Lavan DA, Langer R: Nanoparticle-aptamer bioconjugates: a new approach for targeting prostate cancer cells. Cancer Res 2004, 64:7668-7672.

67. Gu F, Zhang L, Teply BA, Mann N, Wang A, Radovic-Moreno AF, Langer R, Farokhzad OC: Precise engineering of targeted nanoparticles by using self-assembled biointegrated block copolymers. Proc Natl Acad Sci USA 2008, 105:2586-2591.

68. Wang AZ, Bagalkot V, Vasilliou CC, Gu F, Alexis F, Zhang L, Shaikh M, Yuet K, Cima MJ, Langer R, Kantoff PW, Bander NH, Jon S, Farokhzad OC: Superparamagnetic iron oxide nanoparticle-aptamer bioconjugates for combined prostate cancer imaging and therapy. ChemMedChem 2008, 3:1311-1315

69. Zhang L, Radovic-Moreno AF, Alexis F, Gu FX, Basto PA, Bagalkot V, Jon S, Langer RS, Farokhzad OC: Co-delivery of hydrophobic and hydrophilic drugs from nanoparticle-aptamer bioconjugates. ChemMedChem 2007 2:1268-1271.

70. Engels FK, Mathot RA, Verweij J: Alternative drug formulations of docetaxel: a review. Anticancer Drugs 2007, 18:95-103.

71. Cao Z, Tong R, Mishra A, Xu W, Wong GC, Cheng J, Lu Y: Reversible cellspecific drug delivery with aptamer-functionalized liposomes. Angew Chem Int Ed Engl 2009, 48:6494-6498.

72. Ferreira CS, Cheung MC, Missailidis S, Bisland S, Gariepy J: Phototoxic aptamers selectively enter and kill epithelial cancer cells. Nucleic Acids Res 2009, 37:866-876.

73. Chu TC, Marks JW, Lavery LA, Faulkner S, Rosenblum MG, Ellington AD, Levy M: Aptamer:toxin conjugates that specifically target prostate tumor cells. Cancer Res 2006, 66:5989-5992.

74. Chen $\mathrm{CH}$, Dellamaggiore KR, Ouellette CP, Sedano CD, Lizadjohry M, Chernis GA, Gonzales M, Baltasar FE, Fan AL, Myerowitz R, Neufeld EF: Aptamer-based endocytosis of a lysosomal enzyme. Proc Natl Acad Sci USA 2008, 105:15908-15913.

75. Hicke BJ, Stephens AW, Gould T, Chang YF, Lynott CK, Heil J, Borkowski S, Hilger CS, Cook G, Warren S, Schmidt PG: Tumor targeting by an aptamer. J NuCl Med 2006, 47:668-678.

76. Tong GJ, Hsiao SC, Carrico ZM, Francis MB: Viral capsid DNA aptamer conjugates as multivalent cell-targeting vehicles. J Am Chem Soc 2009, 131:11174-11178.

77. Wullner U, Neef I, Eller A, Kleines M, Tur MK, Barth S: Cell-specific induction of apoptosis by rationally designed bivalent aptamer-siRNA transcripts silencing eukaryotic elongation factor 2. Curr Cancer Drug Targets 2008, 8:554-565

78. Lupold SE, Hicke BJ, Lin Y, Coffey DS: Identification and characterization of nuclease-stabilized RNA molecules that bind human prostate cancer cells via the prostate-specific membrane antigen. Cancer Res 2002, 62:4029-4033.

79. Guo KT, Paul A, Schichor C, Ziemer G, Wendel HP: CELL-SELEX: Novel Perspectives of Aptamer-Based Therapeutics. Int J Mol Sci 2008, 9:668-678.

80. Fang X, Tan W: Aptamers Generated from Cell-SELEX for Molecular Medicine: A Chemical Biology Approach. Acc Chem Res 2009, 43(1):48-57.

81. Shangguan D, Cao Z, Meng L, Mallikaratchy P, Sefah K, Wang H, Li Y, Tan W: Cell-specific aptamer probes for membrane protein elucidation in cancer cells. J Proteome Res 2008, 7:2133-2139.

82. Phillips JA, Lopez-Colon D, Zhu Z, Xu Y, Tan W: Applications of aptamers in cancer cell biology. Anal Chim Acta 2008, 621:101-108.

83. Cox JC, Hayhurst A, Hesselberth J, Bayer TS, Georgiou G, Ellington AD: Automated selection of aptamers against protein targets translated in vitro: from gene to aptamer. Nucleic Acids Res 2002, 30:e108.

84. Cox JC, Rudolph P, Ellington AD: Automated RNA selection. Biotechnol Prog 1998, 14:845-850.

85. Nitsche A, Kurth A, Dunkhorst A, Panke O, Sielaff $H$, Junge W, Muth D, Scheller F, Stocklein W, Dahmen C, Pauli G, Kage A: One-step selection of Vaccinia virus-binding DNA aptamers by MonoLEX. BMC Biotechnol 2007, 7:48. 
86. Eulberg D, Buchner K, Maasch C, Klussmann S: Development of an automated in vitro selection protocol to obtain RNA-based aptamers: identification of a biostable substance P antagonist. Nucleic Acids Res 2005, 33:e45.

87. Raddatz MS, Dolf A, Endl E, Knolle P, Famulok M, Mayer G: Enrichment of cell-targeting and population-specific aptamers by fluorescenceactivated cell sorting. Angew Chem Int Ed Engl 2008, 47:5190-5193.

88. Kulbachinskiy AV: Methods for selection of aptamers to protein targets. Biochemistry (Mosc) 2007, 72:1505-1518.

89. Kraus E, James W, Barclay AN: Cutting edge: novel RNA ligands able to bind CD4 antigen and inhibit CD4+ T lymphocyte function. J Immunol 1998, 160:5209-5212

90. Dey AK, Griffiths C, Lea SM, James W: Structural characterization of an anti-gp120 RNA aptamer that neutralizes R5 strains of HIV-1. Rna 2005, 11:873-884.

91. Dey AK, Khati M, Tang M, Wyatt R, Lea SM, James W: An aptamer that neutralizes R5 strains of human immunodeficiency virus type 1 blocks gp120-CCR5 interaction. J Virol 2005, 79:13806-13810.

92. Hicke BJ, Marion C, Chang YF, Gould T, Lynott CK, Parma D, Schmidt PG, Warren S: Tenascin- $C$ aptamers are generated using tumor cells and purified protein. J Biol Chem 2001, 276:48644-48654

93. Shangguan D, Cao ZC, Li Y, Tan W: Aptamers evolved from cultured cancer cells reveal molecular differences of cancer cells in patient samples. Clin Chem 2007, 53:1153-1155.

94. Xiao Z, Shangguan D, Cao Z, Fang X, Tan W: Cell-specific internalization study of an aptamer from whole cell selection. Chemistry 2008, 14:1769-1775.

95. Tasch J, Gong M, Sadelain M, Heston WD: A unique folate hydrolase, prostate-specific membrane antigen (PSMA): a target for immunotherapy?. Crit Rev Immunol 2001, 21:249-261.

96. Liu H, Rajasekaran AK, Moy P, Xia Y, Kim S, Navarro V, Rahmati R, Bander NH: Constitutive and antibody-induced internalization of prostate-specific membrane antigen. Cancer Res 1998, 58:4055-4060.

97. Shi H, Hoffman BE, Lis JT: RNA aptamers as effective protein antagonists in a multicellular organism. Proc Natl Acad Sci USA 1999, 96:10033-10038.

98. Santulli-Marotto S, Nair SK, Rusconi C, Sullenger B, Gilboa E: Multivalent RNA aptamers that inhibit CTLA-4 and enhance tumor immunity. Cancer Res 2003, 63:7483-7489.

99. McNamara JO, Kolonias D, Pastor F, Mittler RS, Chen L, Giangrande PH, Sullenger B, Gilboa E: Multivalent 4-1BB binding aptamers costimulate CD8+ T cells and inhibit tumor growth in mice. J Clin Invest 2008, 118:376-386.

100. Dollins CM, Nair S, Boczkowski D, Lee J, Layzer JM, Gilboa E, Sullenger BA: Assembling OX40 aptamers on a molecular scaffold to create a receptor-activating aptamer. Chem Biol 2008, 15:675-682.

101. Dalgleish AG, Beverley PC, Clapham PR, Crawford DH, Greaves MF, Weiss RA: The CD4 (T4) antigen is an essential component of the receptor for the AIDS retrovirus. Nature 1984, 312:763-767.

102. Hussey RE, Richardson NE, Kowalski M, Brown NR, Chang HC, Siliciano RF, Dorfman T, Walker B, Sodroski J, Reinherz EL: A soluble CD4 protein selectively inhibits HIV replication and syncytium formation. Nature 1988, 331:78-81.

103. Sattentau QJ, Moore JP: The role of CD4 in HIV binding and entry. Philos Trans R Soc Lond B Biol Sci 1993, 342:59-66.

104. Pelchen-Matthews A, Armes JE, Griffiths G, Marsh M: Differential endocytosis of CD4 in lymphocytic and nonlymphocytic cells. J Exp Med 1991, 173:575-587

105. Shu D, Huang LP, Hoeprich S, Guo P: Construction of phi29 DNApackaging RNA monomers, dimers, and trimers with variable sizes and shapes as potential parts for nanodevices. J Nanosci Nanotechnol 2003, 3:295-302.

106. Hoeprich S, Guo P: Computer modeling of three-dimensional structure of DNA-packaging RNA (pRNA) monomer, dimer, and hexamer of Phi29 DNA packaging motor. J Biol Chem 2002, 277:20794-20803.

107. Guo P: RNA nanotechnology: engineering, assembly and applications in detection, gene delivery and therapy. J Nanosci Nanotechnol 2005 5:1964-1982.

108. Klatzmann D, Champagne E, Chamaret S, Gruest J, Guetard D, Hercend T, Gluckman JC, Montagnier L: T-lymphocyte T4 molecule behaves as the receptor for human retrovirus LAV. Nature 1984, 312:767-768.
109. Kwong PD, Wyatt R, Robinson J, Sweet RW, Sodroski J, Hendrickson WA: Structure of an HIV gp120 envelope glycoprotein in complex with the CD4 receptor and a neutralizing human antibody. Nature 1998, 393:648-659.

110. Ugolini S, Mondor I, Sattentau QJ: HIV-1 attachment: another look. Trends Microbiol 1999, 7:144-149.

111. Wyatt R, Sodroski J: The HIV-1 envelope glycoproteins: fusogens, antigens, and immunogens. Science 1998, 280:1884-1888.

112. Sayer N, Ibrahim J, Turner K, Tahiri-Alaoui A, James W: Structural characterization of a 2'F-RNA aptamer that binds a HIV-1 SU glycoprotein, gp120. Biochem Biophys Res Commun 2002, 293:924-931.

113. Khati M, Schuman M, Ibrahim J, Sattentau Q, Gordon S, James W: Neutralization of infectivity of diverse R5 clinical isolates of human immunodeficiency virus type 1 by gp120-binding 2'F-RNA aptamers. J Virol 2003, 77:12692-12698.

doi:10.1186/1758-907X-1-4

Cite this article as: Zhou and Rossi: Aptamer-targeted cell-specific RNA interference. Silence 2010 1:4.

\section{Submit your next manuscript to BioMed Central and take full advantage of:}

- Convenient online submission

- Thorough peer review

- No space constraints or color figure charges

- Immediate publication on acceptance

- Inclusion in PubMed, CAS, Scopus and Google Scholar

- Research which is freely available for redistribution

Submit your manuscript at www.biomedcentral.com/submit
C) Biomed Central 